"Management of collaboration for agricultural innovation systems: a case of constraints among stakeholders in the North West Province, South Africa"

\begin{tabular}{ll} 
AUTHORS & $\begin{array}{l}\text { Modirwa Sinah } \\
\text { Oladimeji I. Oladele }\end{array}$ \\
& $\begin{array}{l}\text { Modirwa Sinah and Oladimeji I. Oladele (2016). Management of } \\
\text { agricultural innovation systems: a case of constraints among stake } \\
\text { North West Province, South Africa. Problems and Perspectives in } \\
\text { ARTICLE INFO }\end{array}$ \\
\hline DOI & http://dx.doi.org/10.21511/ppm.14(1).2016.02 \\
\hline RELEASED ON & Wednesday, 02 March 2016 \\
\hline JOURNAL & "Problems and Perspectives in Management" \\
\hline FOUNDER & LLC "Consulting Publishing Company "Business Perspectives"
\end{tabular}

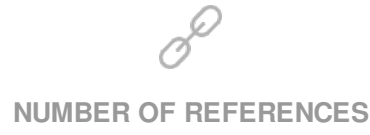

0

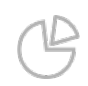

NUMBER OF FIGURES

0

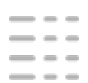

NUMBER OF TABLES

0

C The author(s) 2023. This publication is an open access article. 
Modirwa Sinah (South Africa), Oladimeji I. Oladele (South Africa)

\title{
Management of collaboration for agricultural innovation systems: a case of constraints among stakeholders in the North West Province, South Africa
}

\begin{abstract}
The objective of this paper is to identify constraints hindering collaboration among stakeholders for agricultural innovation system in the North West Province of South Africa. A total sample size of 205 respondents is selected for the study. The study first identifies the characteristics of stakeholders involved in the agricultural innovation system in the North West Province. Data are collected through a structured questionnaire on personal characteristics and constraints hindering collaboration in agricultural innovation system among stakeholders. The data are subjected to analysis using the Statistical Product and Service Solution (SPSS). Descriptive statistics such as frequency distribution, percentages and one way ANOVA are used for analysis. The results revealed that gender has an influence on the adoption of agricultural innovation in the North West Province; farming decisions are dominated by men rather than women, extension agents $(65 \%)$, researchers $(68 \%)$, farmers $(51 \%)$, input dealers $(73 \%)$ and marketers $(70 \%)$. One way analysis of variance results shows no difference in constraint among AIS stakeholders in North West Province. The F value for constraint shows that there is no significant difference among stakeholders in the North West Province.
\end{abstract}

Keywords: management, collaboration, innovation system.

JEL Classification: $\mathrm{O} 32$.

\section{Introduction}

Agricultural innovation system (AIS) is perceived as a vehicle for economic empowerment for rural households making a living from agricultural activities. Adopting agricultural innovation system requires collaboration among stakeholders. Klerks, Schut and Leeuwis (2012a) added that adopting AIS requires insight in the structural conditions provided by the agricultural innovation support system that can either enable or constrain innovation in the agricultural system. According to Hounkonnou, Kossou, Kuyper (2012), within the AIS approach, innovation is perceived as a process of combined technological (such as cultivars, fertilizer, agronomic practices) and non-technological (such as social practices including labor organizations or institutional settings such as land-tenure arrangement) changes. Kilelu, Klerks and Leeuwis (2013) add that such changes occur across different levels: in the farm, field and region and are shaped by collaboration amongst stakeholders and organizations inside and outside the agricultural sector. Rolling (2009) asserts that in the AIS approach, innovation is considered the result of a process of networking and interactive learning among a heterogeneous set of actors, such as farmers, input industries, processors, traders, researchers, extensionists, government official, and civil society organizations. This indicates that agricultural innovation is not only about introducing new

(C) Modirwa Sinah, Oladimeji I.Oladele, 2015.

Modirwa Sinah, Ph.D., Department of Agricultural Economics and Extension, North West University, Mafikeng campus, South Africa.

Oladimeji I. Oladele, Ph.D., Professor, Department of Agricultural Economics and Extension, North West University, Mafikeng campus, South Africa. technologies but also about institutional change as it requires new ways of managing and organizing. Agriculture is evolving in an environment of rapid changes, in technology, markets, policies, demography and natural resources; it is important that all actors in the agricultural sector must innovate and develop new ways of collaborating to generate knowledge and put it into use at the required pace (Daane, 2010; and Hansen, Jespersen, Brunori, 2014).

World Bank (2012) noted that variety of methods have been developed and applied that can support agricultural innovation system and they were never successful. Investigating the constraints for stakeholder collaboration is essential to enhance agricultural production; however, collaboration relies on trust and constructive engagement for actors to achieve a broad common purpose. To achieve this, it is important to identify barriers and create respective roles of the government, private sector, farmers and researchers. Stakeholder collaboration can provide enhanced insight to the extent of the constraints and the feasible solutions. Klekx and Gildemacher (2012) noted that the constraint to collaboration among stakeholders for agricultural innovation system is often not the results of unwillingness to interact but lack of capacity, structures and incentives to interact effectively. However, through collaboration in agricultural innovation system, communication amongst stakeholders can improve greatly. The objectives of the study are to: Identify the characteristics of stakeholders for agricultural innovation system in the North West Province, South Africa and identify constraints to collaboration among stakeholders. 


\section{Literature}

Innovations of agricultural suppliers, producers and retailers are directly or indirectly shaping sustainability within the agro food-web. If sustainable innovations are targeted, the key challenges faced by agriculture worldwide, such as food security, climate change, should be promoted. Knowledge about current innovation processes is needed to reveal mechanisms that allow for promoting sustainable agricultural innovations (Kunig, Kuntosch, Bokelmann, 2012). Innovation is defined differently by different authors, Anandajayasekeram (2009) defines it as "the technical, design, manufacturing, management and commercial activities involved in the marketing of a new (or improved) product or the first commercial use of a new (or improved) process or equipment", whereas Hristov (2011) defines it as "all important economic, social, political, organizational, institutional, and other factors that influence the development, diffusion and use of innovations". Innovations are new creations of economic significance and relate to the production of new knowledge and/or new combination of existing knowledge. The critical point to note is that this knowledge cannot be regarded as innovation unless it is transformed into products and processes that have social and economic use.

A system is a collection of related elements that must function in concert in order to achieve a desired result. It consists of interlinked subsystems. A system contains one or more feedback loops which are central to the system behavior and permits a system to function in a self-managed, selfsustained way. Ponniah and Gebremedhin (2009) add that the application of the systems in agricultural and Rural Development started with the farming systems and has expanded to the application in organization and institutional analysis, resulting in the agricultural innovation systems. Agricultural innovation system occurs through dynamic interaction among the multitudes of actors involved in growing, processing, packaging, distributing and consuming of agricultural products. These actors have different skills, therefore, interaction among them needs to open and draw upon the most appropriate knowledge. The ability to innovate is related to collective action, coordination and the exchange of knowledge among multiple actors, the incentives and resources available to form partnership and develop business and conditions that make it possible for farmers to use the innovation. Research, education and extension are not enough to bring knowledge, technologies and service to farmers and get them innovate. Innovation requires a more interactive, dynamic and flexible process in which actors coordinate their efforts with various conditions and complementary activities that go beyond extension. The agricultural innovation system caters for various conditions and relationships that promote innovation in agriculture, considers diverse actors, their potential interaction in promoting innovation. Agricultural innovation system supports research, extension and education and creates links among extension and farmers for innovation to take place (World Bank, 2012).

The importance of promoting agricultural innovation system is that it builds on local knowledge and resources, which results in ownership and continuity of initiatives, while addressing the priority needs of beneficiaries or communities for improved livelihoods. The agricultural innovation system approach allows for collaboration and communication among stakeholders, which is subsequent to social learning. Stakeholders are able to identify and recognise their experimentation efforts, responsibilities, strengths and weaknesses, thereby strengthening participation and community innovation processes.

\section{Methodology}

2.1. Study area. The study was conducted in the North West Province of South Africa. It covered four districts, namely, Dr Segomotsi Mompati, Ngaka Modiri Molema, Dr Kenneth Kaunda and the Bojanala Platinum. The Province lies between 22 and 28 degrees longitude east of the Greenwich meridian, covering $116320 \mathrm{~km}^{2}$ or about $9.5 \%$ of South Africa's total surface area. The North West province shares boundaries with the Northern Cape in the west, the Free State in the south, Gauteng in the east and Limpopo (formerly Nothern Cape) in the east (DAFF, 2000). The Province is also characterized by great seasonal and daily variations in temperatures ranging from $17^{\circ}$ to $31^{\circ}$ Celsius in summer and $3^{\circ}$ to $21^{\circ}$ Celsius in winter. Annual rainfall totals about $360 \mathrm{~mm}$, falling during the summer months, between October and April. The North West has the largest cattle herds found in Stella near Vryburg. The areas around Brits and Rustenburg are fertile, providing mixed crop farming land. Maize and sunflowers are the most important crops and the North West is the major producer of white maize in the country.

A list of researchers, extension agents and farmers was obtained from their respective organizations within the North West province and the list served as a sampling frame for the study. For input dealers and marketers, there was no definite sampling frame. The frame for different groups was as 
follows: Extension agents from the Department of Agriculture and Rural Development (195), researchers from agricultural research and the North West University (135), registered farmers from African Farmers Association of South Africa, the National African Farmers Union and the North West Emerging Red Meat Producer Organization (195). Simple random sampling technique was used to select respondents because each individual has the same probability of being chosen at any stage during the sampling process. The researcher decided to contact a maximum number of respondents but due to order situations in the province, a large sample size of $n \geq 30$ was used to select the farmers, extension agents, researchers, marketers and input dealers for agricultural innovation system. A total of 205 respondents were randomly selected as follows: 60 extension agents, 50 researchers, 35 farmers, 30 input dealers and 30 marketers.

Data were generated from primary sources based on the objectives of the study. An interview schedule was used to elicit information from respondents. Data were collected through a structured questionnaire developed based on the study objectives and review of the relevant literature. Close-ended questions were used to collect demographic information such as gender, age, household size, religion, educational level and working experience in the first section. The second section focused on the constraints hindering collaboration among respondents, and was measured in a two point scale of Yes (2) and No (1).

Data collected were sorted, coded and analyzed using the Statistical Product and Service Solution (SPSS). The data collected were analyzed using both descriptive statistics such as percentage and frequency distribution. Analysis of variance was used to measure constraints hindering collaboration among farmers, extension agents, researchers, input dealers and marketers.

2.2. Results and discussion. The first objective of the study was to identify the characteristics of stakeholders for agricultural innovation system in the North West Province. Table 1 indicates that extension agents were predominantly males $(65 \%)$ and only $35 \%$ were females. This might be attributed to socio-cultural factors which favor men. Oladele (2011) maintains that it is a wide belief that males are dominating in the agricultural sector compared to females.

Martey, Etwire, Wiredu and Dogbe (2014) point out that females usually lack access to agricultural resources that enhance their participation in social activities and innovation.
Table 1 also presents the age of respondents; about $50 \%$ (extension agents), 46\% (farmers) and 60\% (marketers) are over fifty years respectively. Input dealers $(40 \%)$ fall within the range of 41-49 years. This implies that they are in the productive stage and this would help increase food production. However, researchers $(56 \%)$ were found to be less than 40 years of age.

Furthermore Table 1 presents the marital status of the respondents. It was found that researchers $(64 \%)$ farmers $(71 \%)$ were married; it further reveals that input dealers $(70 \%)$ and marketers $(90 \%)$ were married. Nnadi and Akwiwu (2008) found that marriage increases one's concern for household welfare and food security which is therefore likely to have a positive effect on their decision to participate in an agricultural project.

Household size is also presented in Table 1. About $52 \%$ of extension agents, $58 \%$ of researchers, $58 \%$ of farmers, $73 \%$ of input dealers and $74 \%$ of marketers revealed that their household size falls within the bracket of 3 to 5 persons. This might be because of the fact that the cost of living has become too high and people prefer to have fewer family members. This is contrary to the findings of Wiredu, Martey and Etwire (2013) who found that household size serves as a form of family labor and complements the efforts of household heads on the farm.

Table 1 further presents the educational level of respondents. $40 \%$ of the extension agents have a degree or qualification, $52 \%$ of researchers have a master's degree, $40 \%$ of farmers have certificates, $53 \%$ of input dealers have a diploma and $90 \%$ of marketers have certificates. This shows that respondents can make decisions. Enete and Igbokwe (2009) found that education enables people to make independent choices and act on the basis of the decision. It further increases the tendency to collaborate with others and participate in group activities.

Table 1 further reveals the distribution for studying for a higher qualification. A high percentage of respondents were found not to be studying for a higher qualification $(52 \%$ of extension agents and $58 \%$ of researchers) and this might be as a result of the higher qualifications they already have. However, some of them indicated that their workload makes it difficult for them to pursue their studies. Farmers $(83 \%)$ indicated that it is difficult for them to further studies because in addition to farm the work, they also have family responsibilities. Input dealers represented $70 \%$ and marketers $-97 \%$.

The findings in Table 1 depict that $37 \%$ of extension agents have more than 20 years of working 
experience compared to $38 \%$ of researchers, and $46 \%$ of farmers. This is contrary to Adesoji, Farinde and Ajayi (2006) who found that only $22 \%$ of farmers have more than ten years of farming experience. Furthermore, $44 \%$ of input dealers were found to have working experience of 6 to 10 years. However, long work experience is helpful because it enables one to understand what working environments are like and to adhere to the conditions, and demonstrate the best of his/her ability.

Table 1. Demographic characteristics of respondents

\begin{tabular}{|c|c|c|c|c|c|c|c|c|c|c|}
\hline \multirow[b]{2}{*}{ Variables } & \multicolumn{2}{|c|}{ Extension } & \multicolumn{2}{|c|}{ Researchers } & \multicolumn{2}{|c|}{ Farmers } & \multicolumn{2}{|c|}{ Input dealers } & \multicolumn{2}{|c|}{ Marketers } \\
\hline & Frequency & $\%$ & Frequency & $\%$ & Frequency & $\%$ & Frequency & $\%$ & Frequency & $\%$ \\
\hline \multicolumn{11}{|l|}{ Gender } \\
\hline Male & 39 & 65 & 34 & 68 & 18 & 51 & 22 & 73 & 21 & 70 \\
\hline Female & 21 & 35 & 16 & 32 & 17 & 49 & 8 & 27 & 9 & 30 \\
\hline \multicolumn{11}{|l|}{ Age } \\
\hline$<40$ years & 16 & 27 & 28 & 56 & 12 & 34 & 10 & 33 & 4 & 13 \\
\hline 41-49 years & 14 & 23 & 13 & 26 & 7 & 20 & 12 & 40 & 8 & 27 \\
\hline$>50$ years & 30 & 50 & 9 & 18 & 16 & 46 & 8 & 27 & 18 & 60 \\
\hline \multicolumn{11}{|l|}{ Marital status } \\
\hline Single & 51 & 85 & 15 & 30 & 7 & 20 & 7 & 23 & 1 & 3 \\
\hline Married & 2 & 3 & 32 & 64 & 25 & 71 & 21 & 70 & 27 & 90 \\
\hline Divorced & 7 & 12 & 3 & 6 & 0 & 0 & 1 & 3 & 1 & 3 \\
\hline Widowed & 0 & 0 & 0 & 0 & 3 & 9 & 1 & 3 & 1 & 3 \\
\hline \multicolumn{11}{|l|}{ Household size } \\
\hline 1-2 members & 11 & 18 & 14 & 28 & 0 & 0 & 1 & 3 & 4 & 13 \\
\hline 3-5 members & 31 & 52 & 29 & 58 & 20 & 58 & 22 & 73 & 22 & 74 \\
\hline$>5$ members & 18 & 30 & 7 & 14 & 15 & 43 & 7 & 23 & 4 & 13 \\
\hline \multicolumn{11}{|l|}{ Highest educ. level } \\
\hline No formal education & 0 & 0 & 0 & 0 & 11 & 31 & 0 & 0 & 0 & 0 \\
\hline Certificate & 12 & 20 & 0 & 0 & 14 & 40 & 6 & 20 & 27 & 90 \\
\hline Diploma & 18 & 30 & 0 & 0 & 8 & 23 & 16 & 53 & 3 & 10 \\
\hline Degree & 24 & 40 & 3 & 6 & 1 & 3 & 7 & 23 & 0 & 0 \\
\hline Honors & 5 & 8 & 5 & 10 & 1 & 3 & 1 & 3 & 0 & 0 \\
\hline Masters & 1 & 2 & 26 & 52 & 0 & 0 & 0 & 0 & 0 & 0 \\
\hline $\mathrm{PhD}$ & 0 & 0 & 16 & 32 & 0 & 0 & 0 & 0 & 0 & 0 \\
\hline \multicolumn{11}{|c|}{ Studying for a higher qualification } \\
\hline Yes & 29 & 48 & 21 & 42 & 5 & 17 & 9 & 30 & 1 & 3 \\
\hline No & 31 & 52 & 29 & 58 & 30 & 83 & 21 & 70 & 29 & 97 \\
\hline \multicolumn{11}{|l|}{ Working experience } \\
\hline $1-5$ years & 5 & 8 & 12 & 20 & 6 & 17 & 4 & 13 & - & - \\
\hline $6-10$ years & 15 & 25 & 19 & 38 & 16 & 46 & 13 & 44 & - & - \\
\hline $11-15$ years & 14 & 23 & 8 & 16 & 3 & 9 & 7 & 23 & - & - \\
\hline $16-20$ years & 4 & 7 & 3 & 6 & 4 & 11 & 3 & 10 & - & - \\
\hline$>20$ years & 22 & 37 & 8 & 16 & 6 & 17 & 3 & 10 & - & - \\
\hline
\end{tabular}

\section{Constraints to collaboration}

Collaboration comes in varied forms and is often derived out of a need to provide knowledge and skills. Collaboration evolves and may be terminated once the objectives of the stakeholders have been achieved or modified. Therefore, collaboration can either be rewarding or risky at the same time (Freeman, Ganguli and Murciano-Gorof, 2014). Table 2 presents results of the study with regard to constraint faced by researchers, input dealers and marketers. Constraints ranked by researchers were as follows: status among stakeholders $(96 \%)$, poor administration of research and extension institutions, lack of recognition from colleagues both at (92\%) job tenure of researchers $(90 \%)$, conflicting ideas and limited resources (86\%). Ubfal (2010) found that private mechanisms of funding are not widespread in developing countries and public funding was found to be the option for researchers. He further identified poor infrastructure for scientific research.

Moreover, constraints ranked highest by input dealers were as follows: Inadequate finance for technology (93\%), status among stakeholders (93\%), professional bias (93\%), poor administration of research and extension institutions (93\%), conflicting ideas (90\%), 
lack of recognition from colleagues $(90 \%)$, lack of interest $(87 \%)$, limited resources $(87 \%)$ and key decision-makers difficult to contact (87\%). Contrary to these findings, Jonas, Mairura and Ekisa (2008) found high transport costs due to poor infrastructure, lack of market information, lack of storage facilities and limited skills among input dealers as major constraints to collaboration.

Furthermore, constraints ranked highly by marketers were as follows: political issues influencing research and extension, lack of recognition from colleagues, not aware of existing technology (87\%), isolation and scattered habitat from farmers, inadequate research staff, poor administration of research and extension (83\%). Antwi and Seahlodi (2011) found the problem of accessing the high value market as a constraint to collaboration.

Extension agents indicated that their major constraints to collaboration are as follows: inadequate research staff (98\%), lack of interest (93\%), poor administration of research and extension institutions (93\%), job tenure of extension agents (92\%), inadequate finance for technologies $(90 \%)$, no consultation $(88 \%)$, lack of communication among stakeholders (88\%), professional bias (85\%), job tenure of researchers (85\%), status among stakeholders $(83 \%)$ and political issues influencing research and extension (83\%). However, Farooq (2010) found that inadequate research staff, lack of teaching equipment/facilities, poor linkages between research and extension organizations as the main obstacle hindering collaboration. In addition, Ajani and Onwubuya (2013) maintain that inadequate numbers and qualifications of extension agents create problems for extension agents to collaborate.

Prominent constraints to collaboration as ranked by farmers were as follows: inadequate finance for technologies and conflicting ideas both at (97\%), no consultation and no complement from colleagues (94\%), lack of communication among stakeholders, isolation and scattered habitat of farmers and inappropriate technologies (87\%). These problems prevent farmers from abiding with the advice of extension workers and hence tend to be left behind in the adoption of the innovation process. According to Apantaku (2006), factors identified by farmers are low encouragement, inadequate knowledge and skills.

Table 2. Constraints to collaboration faced by extension agents, farmers, researchers, input dealers and marketers

\begin{tabular}{|c|c|c|c|c|c|c|c|c|c|c|}
\hline \multirow{2}{*}{ Constraint } & \multicolumn{2}{|c|}{ Extension agents } & \multicolumn{2}{|c|}{ Farmers } & \multicolumn{2}{|c|}{ Researchers } & \multicolumn{2}{|c|}{ Input dealers } & \multicolumn{2}{|c|}{ Marketers } \\
\hline & $\mathrm{Y}$ & $\mathrm{N}$ & $\mathrm{Y}$ & $\mathrm{N}$ & $\mathrm{Y}$ & $\mathrm{N}$ & $\mathrm{Y}$ & $\mathrm{N}$ & $\mathrm{Y}$ & $\mathrm{N}$ \\
\hline Inadequate extension staff & $42(70)$ & $18(30)$ & $25(71)$ & $10(27)$ & $40(80)$ & $10(20)$ & $29(27)$ & $1(3)$ & $21(70)$ & $9(30)$ \\
\hline Inadequate farmer participation & $35(58)$ & $25(42)$ & $6(17)$ & $29(83)$ & $19(38)$ & $31(62)$ & $13(43)$ & $17(57)$ & $22(73)$ & $8(27)$ \\
\hline Lack of information on new technology & $25(42)$ & $35(58)$ & $13(37)$ & $22(63)$ & $24(40)$ & $26(52)$ & $17(57)$ & $13(43)$ & $22(73)$ & $8(27)$ \\
\hline Inadequate finance for technologies & $54(90)$ & $6(10)$ & $34(97)$ & $1(3)$ & $34(68)$ & $16(32)$ & $28(93)$ & $2(7)$ & $22(73)$ & $8(27)$ \\
\hline Conflicting ideas & $43(72)$ & $17(28)$ & $34(97)$ & $1(3)$ & $43(86)$ & $7(14)$ & $27(90)$ & $3(10)$ & $22(73)$ & $8(27)$ \\
\hline No consultation & $53(88)$ & $7(12)$ & $33(94)$ & $2(6)$ & $38(76)$ & $12(24)$ & $21(70)$ & $9(30)$ & $21(70)$ & $9(30)$ \\
\hline Lack of communication among stakeholders & $53(88)$ & $7(12)$ & $31(89)$ & $4(11)$ & $30(60)$ & $20(40)$ & $24(80)$ & $6(20)$ & $23(77)$ & $7(23)$ \\
\hline Status among stakeholders & $50(83)$ & $10(17)$ & $28(80)$ & $7(20)$ & $48(96)$ & $2(4)$ & $28(93)$ & $2(7)$ & $23(77)$ & $7(23)$ \\
\hline Lack of complement from colleagues & $41(68)$ & $19(32)$ & $33(94)$ & $2(6)$ & $40(80)$ & $10(20)$ & $19(63)$ & $11(37)$ & $23(77)$ & $7(23)$ \\
\hline Poor management & $45(75)$ & $15(25)$ & $32(91)$ & $3(9)$ & $36(72)$ & $14(28)$ & $17(57)$ & $13(43)$ & $22(73)$ & $8(27)$ \\
\hline Lack of skilled staff & $34(7)$ & $26(43)$ & $28(80)$ & $7(20)$ & $36(72)$ & $14(28)$ & $17(57)$ & $13(43)$ & $24(80)$ & $6(20)$ \\
\hline Isolation and scattered habitat of farmers & $20(33)$ & $40(67)$ & $31(87)$ & $4(11)$ & $27(54)$ & $23(46)$ & $23(77)$ & $7(23)$ & $25(83)$ & $5(17)$ \\
\hline Lack of trust & $48(80)$ & $12(20)$ & $19(54)$ & $16(46)$ & $34(68)$ & $16(32)$ & $26(87)$ & $4(14)$ & $23(77)$ & $7(23)$ \\
\hline Lack of interest & $56(93)$ & $4(7)$ & $23(64)$ & $12(34)$ & $28(56)$ & $22(44)$ & $19(63)$ & $11(37)$ & $23(77)$ & $7(23)$ \\
\hline Inappropriate technologies & $49(82)$ & $11(18)$ & $31(87)$ & $4(11)$ & $36(72)$ & $14(28)$ & $16(53)$ & $14(47)$ & $24(80)$ & $6(20)$ \\
\hline Professional bias & $51(85)$ & $9(15)$ & $26(74)$ & $9(30)$ & $35(70)$ & $15(30)$ & $28(93)$ & $2(7)$ & $24(80)$ & $6(20)$ \\
\hline Limited resources & $49(82)$ & $11(18)$ & $25(71)$ & $10(29)$ & $43(86)$ & $7(14)$ & $26(87)$ & $4(14)$ & $24(80)$ & $6(20)$ \\
\hline Inexperienced staff & $49(82)$ & $11(18)$ & $27(77)$ & $8(23)$ & $37(74)$ & $13(26)$ & $22(73)$ & $8(27)$ & $24(80)$ & $6(20)$ \\
\hline Key decision makers difficult to contact & $42(70)$ & $18(30)$ & $26(74)$ & $9(26)$ & $35(70)$ & $15(30)$ & $26(87)$ & $4(14)$ & $24(80)$ & $6(20)$ \\
\hline Unclear project scope & $25(42)$ & $35(58)$ & $17(49)$ & $18(51)$ & $25(50)$ & $25(50)$ & $21(70)$ & $9(30)$ & $23(77)$ & $7(23)$ \\
\hline Lack of time & $29(48)$ & $31(52)$ & $23(66)$ & $12(34)$ & $38(76)$ & $12(24)$ & $22(73)$ & $8(27)$ & $24(80)$ & $6(20)$ \\
\hline Different expectations & $43(72)$ & $17(28)$ & $25(71)$ & $10(29)$ & $34(68)$ & $16(32)$ & $22(73)$ & $8(27)$ & $27(90)$ & $3(10)$ \\
\hline Job tenure of researchers & $51(85)$ & $9(15)$ & $16(46)$ & $19(54)$ & $45(90)$ & $5(10)$ & $25(83)$ & $5(17)$ & $23(77)$ & $7(23)$ \\
\hline Job tenure of extension agents & $55(92)$ & $5(8)$ & $24(67)$ & $11(31)$ & $40(80)$ & $10(20)$ & $24(80)$ & $6(20)$ & $23(77)$ & $7(23)$ \\
\hline Qualification of extension agents & $45(75)$ & $15(25)$ & $21(60)$ & $14(20)$ & $40(80)$ & $10(20)$ & $14(47)$ & $16(53)$ & $23(77)$ & $7(23)$ \\
\hline Political issues influencing research \& extension & $50(83)$ & $10(17)$ & $28(80)$ & $7(20)$ & $41(82)$ & $9(18)$ & $29(27)$ & $1(3)$ & $26(87)$ & $4(13)$ \\
\hline Inadequate research staff & $59(98)$ & $1(2)$ & $17(49)$ & $18(51)$ & $11(22)$ & $39(78)$ & $29(27)$ & $1(3)$ & $25(83)$ & $5(17)$ \\
\hline
\end{tabular}


Table 2 (cont.). Constraints to collaboration faced by extension agents, farmers, researchers, input dealers and marketers

\begin{tabular}{|l|c|c|c|c|c|c|c|c|c|c|}
\hline \multirow{2}{*}{ Constraint } & \multicolumn{2}{|c|}{ Extension agents } & \multicolumn{2}{c|}{ Farmers } & \multicolumn{2}{c|}{ Researchers } & \multicolumn{2}{|c|}{ Input dealers } & \multicolumn{2}{c|}{ Marketers } \\
\cline { 2 - 12 } & $\mathrm{Y}$ & $\mathrm{N}$ & $\mathrm{Y}$ & $\mathrm{N}$ & $\mathrm{Y}$ & $\mathrm{N}$ & $\mathrm{Y}$ & $\mathrm{N}$ & $\mathrm{Y}$ & $\mathrm{N}$ \\
\hline Poor administration of research \& extension institutions & $56(93.3$ & $4(7)$ & $22(63)$ & $13(37)$ & $46(92)$ & $4(8)$ & $28(93)$ & $2(7)$ & $25(83)$ & $5(17)$ \\
\hline Lack of recognition from colleagues & $42(70)$ & $18(30)$ & $24(69)$ & $11(31)$ & $46(92)$ & $4(8)$ & $27(90)$ & $3(10)$ & $26(87)$ & $4(13)$ \\
\hline Lack of interest & $42(70)$ & $18(30)$ & $20(57)$ & $15(43)$ & $32(64)$ & $18(38)$ & $25(83)$ & $5(17)$ & $24(80)$ & $6(20)$ \\
\hline Distance between research centres and extension & $31(52)$ & $29(48)$ & $21(60)$ & $14(40)$ & $39(78)$ & $11(22)$ & $22(73)$ & $8(27)$ & $25(83)$ & $5(17)$ \\
\hline
\end{tabular}

One way ANOVA showing difference among stakeholders for agricultural innovation system in the North West Province

In Table 3, with one way analysis of variance, results show no difference in constraint among AIS stakeholders in North West Province. The F value shows that there is no significant difference among stakeholders in the North West Province.

Table 3. One way ANOVA showing differences among stakeholders for agricultural innovation in the North West Province

\begin{tabular}{|l|c|c|c|c|c|l|}
\hline \multicolumn{1}{|c|}{ Constraint } & $\begin{array}{c}\text { Sum of } \\
\text { squares }\end{array}$ & DF & $\begin{array}{c}\text { Mean } \\
\text { square }\end{array}$ & F & SIG & Remarks \\
\hline Btw groups & 157.833 & 4 & 39.458 & 1.173 & .321 & $\begin{array}{l}\text { No significant } \\
\text { difference } \\
\text { (post-hoc not } \\
\text { necessary) }\end{array}$ \\
\hline Within groups & 6726.723 & 200 & 33.634 & & & \\
\hline Total & 6884.556 & 204 & & & &
\end{tabular}

\section{Conclusion}

The focus of this study was to identify constraints to collaboration among stakeholders for agricultural innovation system. Innovation is essential for agricultural development.

Gender has an influence on the adoption of agricultural innovation in the North West Province. Farming decisions are dominated by men rather than women. Attention to gender will improve the efficiency of an organization through targeting both men and women. It is important that women and men have equality of opportunity as an important priority. It is also a necessity for the sustainability of rural development programs. Equal opportunities must be integrated in the design and implementation of rural development programs and projects. Constraints that were ranked high by the stakeholders need to be mitigated as their hindrance to collaboration can be detrimental to agricultural productivity. One way analysis of variance results showed no difference in constraint among AIS stakeholders in North West Province. The F value for constraint shows that there is no significant difference among stakeholders in the North West Province.

\section{References}

1. Adesoji, S.A., Faride, A.J. and Ajayi, O.A. (2006). Assessment in the training needs of Fadama farmers for future agricultural extension work development in Osun State, Nigeria, Journal of Applied Science, 6 (15), pp. 3089-3095.

2. Ajani, E.N., Onwubuya, E.A. (2013). Constraints to Effective Communication among Extension Agents, Journal of Agricultural and Food Information, 14 (1), pp. 18-25. Available at: http://www.dx.doi.org/10.

3. Anandajayasekeram, P. (2009). Integrating innovation systems perspective and value chain analysis in agricultural research for development: Implications and challenges: International Livestock Research Institute (ILRI), Addis Ababa, Ethiopia. Available at: https://cgspace.cgiar.org/bitstream/handle/10568/513/ IPMS\%20Working\%20paper\%2016.pdf?sequence=1. Accessed 2014.

4. Antwi, M., Seahlodi, P. (2011). Marketing constraints facing emerging farmers, Journal of Human Ecology, 36 (1), pp. 37-42. Available at: http://www.krepublishers.com/02-journals.

5. Apantaku, S.O. (2006). Analysis of participation of farmers in participatory poultry production research in Lagos state, Nigeria, Livestock Research for Rural Development, 18 (7), pp. 102-107.

6. Daane, J. (2010). Enhancing performance of agricultural innovation systems, Rural Development News, 1. Available at: http://www.agri-international.ch/fileadmin/10_International/PDF/RDN/RDN_2010/15_performance.pdf. Accessed 2013.

7. Enete, A.A., Igbokwe, E.M. (2009). Cassava market participation decision of household in Africa, Tropicultura, 27 (3), pp. 129-136. Available at: http://www.agrifoodecon.com. Accessed June 2013.

8. Farooq, A.M., Ishaq, N.A. Shah, N.A., Karim, R. (2010). Agriculture Extension agents and challenges for sustainable development, Sarhad J. Agric, 26 (3), pp. 419-426.

9. Freeman, Richard B., Ina Ganguli and Raviv Murciano-Goroff. (2014). Why and Wherefore of Increased Scientific Collaboration, NBER Working Paper No. 19819, Issued in January 2014. Available at: http://www.Nber.org. Accessed July 2014.

10. Hansen, J.P., Jesperson, L.M., Brunori, G., Jensen, A.L. (2014). ICT and social media as drivers of multi-actor innovation in agriculture, World Conference on Computers in Agriculture and Natural Resources, University of Costa Rica, San Jose Costa Rica, July 27th-30th. Available at: http://CIGRProceedings.org.

11. Hounkonnou, D., Kossou, D., Kuyper, T.W., Leeuwis, C., Nederlof, E.S. (2012). An innovation systems approach to institutional change: Smaller development in West Africa, Agricultural Systems, 108, pp. 74-83. 
12. Hristov, M. (2011). The agricultural Innovation system: The knowledge issues in the Bulgarian Agricultural sector. Available at: http://www.prekter.aau.dk/projecter/files/54936694/SI.pdf.

13. Jonas, N., Mairura, F., Ekisa, I., Chianu, J.N. (2008). Farm Input marketing in Western Kenya: Challenges and opportunities, African Journal of Agricultural Research, 3 (3), pp. 167-173.

14. Kilelu, C.W., Klerkx, L., Leeuwis, C. (2013). Unravelling the role of innovation platforms in supporting coevolution of innovation: contributors and tensions in a smallholder dairy development programme, Agricultural Systems, 118, pp. 65-77.

15. Klerkx, L., Schut, M., Leeuwis, C. (2012a). Advance in Knowledge brokering in the agricultural sector: towards innovation system facilitation, IDS Bull, 43, pp. 53-60.

16. Klekx, L. and Gildemacher, P. (2012). The role of Innovation Brokers in Agricultural Innovation Systems. Wageningen University: Netherlands. Available at: http://innovationspolicyplatform.org. Accessed August 2015.

17. Kunig, B., Anett Kuntosch, A., Wolfgang Bokelmann, Alexandra Doernberg, Wim Schwerdtner, Maria Busse, Rosemarie Siebert, Knut Koschatzky and Thomas Stahlecker. (2012). Innovation for Agricultural Competitiveness and Sustainability of Rural Areas. Prague, Czech Republic. Available at: http://ageconsearch.umn.edu/ bitstream/135792/2/Konig.pdf. Accessed 2014.

18. Martey, E., Etwire, P.M., Alexander, N.W. and Dogbe, W. (2014). Agricultural and Food Economics: Factors influencing willingness to participate in multi-stakeholder platform by smallholder farmers in Northern Ghana: Implication for research and development. Tamale, Ghana. Available at: http://www.agrifoodecon.com/content/2/1/11.

19. Nnadi, F.N. and Akwiwu, C.D. (2008). Determinants of Youths' Participation in Rural Agriculture in Imo State, Nigeria, Journal of Applied Sciences, 8 (2), pp. 328-333.

20. Oladele, O.I. (2011). Features of Agricultural Extension Models and Policy in selected Sub-Saharan Countries, Journal of Agriculture and Environment for International Development, 105 (1), pp. 35-34.

21. Ponniah, A. and Gebremedhin, B. (2009). Improving the Productivity of Market Access of Ethiopia. Addis Ababa. Available at: http://books.google.co.za/books?id=XErnrlNumFoC\&pg=PA73\&lpg=PA73\&dq. Accessed 2014.

22. Ruling, N. (2009). Pathways for impact: scientists' different perspectives on agricultural innovation, International Journal of Agricultural Sustainability, 7, pp. 83-94.

23. Ubfal, D. (2010). Making Innovation work for society: Linking, Leveraging and Learning. Kuala Lampur. Malaysia.

24. Wiredu, N.A., Martey, E., Etwire, M., Dogbe, W. (2013). Factors Influencing Willingness to participate in multistakeholder Platform by small-holder farmers in Northern Ghana: Implication for research and development. Tamale. Ghana. Available at: http://www.agri.foodcon.com. Accessed September 2014.

25. World Bank. (2012). Agricultural Innovation systems: an investment Sourcebook. The World Bank. Washington, D.C. 